\title{
Penerapan Kompres Jahe Untuk Mengurangi Nyeri Pada Lansia Penderita Asam Urat
}

\author{
Muhammad Lutfi ${ }^{1 *}$, Dwi Fijianto ${ }^{2}$ \\ 1,2 Program Studi Diploma Tiga Keperawatan, Universitas Muhammadiyah Pekajangan \\ Pekalongan, Indonesia \\ *email:muhamadlutfi1001@gmail.com
}

\begin{abstract}
Gout is a disease that attacks the joint area, caused by consuming too many foods with high purine content, and sufferers feel pain and swelling in the joints. One ofthe ways to reduce pain by compressing with ginger. This study aims to apply the way in order to reduce on the elderly with gout. The result stated both have decreased pain scale. The first patients has decreased the scalen from 5 to 2 , and the latter had decreased the scale from 4 to 2 , Furthermore, the patients and the family finally have understood the treatment of gout. Therefore, it can be concluded that compressing theraphy with ginger can reduce pain in the joints of eldery patients with gout. Thus, it is expected for the nursing staff to teach the theraphy on the patient and the family
\end{abstract}

Keywords : gout; compressing with ginger; elderly

\begin{abstract}
Abstrak
Asam urat merupakan penyakit yang menyerang pada area sendi yang disebabkan banyaknya mengonsumsi makanan dengan kandungan purin tinggi dengan keluhan nyeri dan bengkak pada sendi. Tindakan untuk mengurangi nyeri salah satunya adalah kompres jahe. Tujuan dari studi kasus ini adalah menerapkan kompres jahe untuk mengurangi nyeri pada lansia penderita asam urat.Metode yang digunakan adalah metode deskriptif, yaitu metode yang digunakan untuk menganalisis data dengan cara mendeskripsikan atau menggambarkan data yang telah terkumpul. Hasil studi kasus ini pasien I dan II terjadi penurunan skala nyeri pasien I dari skala 5 menjadi 2 dan pasien II dari skala 4 menjadi 2, serta memahami perawatan pada asam urat. Kesimpulan studi kasus ini bahwa terapi kompres jahe dapat menurunkan nyeri pada persendian pasien lansia penderita asam urat. Saran untuk perawat diharapkan mengajarkan cara mengatasi penyakit asam urat dengan menggunakan terapi kompres jahe.
\end{abstract}

Kata kunci : Asam urat;, kompres jahe; lansia

\section{Pendahuluan}

Penderita asam urat di dunia mengalami kenaikan jumlah penderita sampai dua kali lipat antara tahun 1990 - 2010. Penderita asam urat usia dewasa di Amerika Serikat penyakit ini menunjukan peningkatan dan mempengaruhi 8.3 juta (4\%) orang Amerika. Prevalensi hiperurisemia atau kadar asam urat normal juga meningkat dan mempengaruhi 43.300 .000 (21\%) orang dewasa di Amerika Serikat (Jaliana dkk, 2018).

Kemenkes, (2013) menyatakan bahwa penyakit sendi di Indonesia yang diagnosis tenaga kesehatan sekitar $11.9 \%$ dan berdasarkan diagnosis dan gejala sebesar 24.7\%, sedangkan berdasarkan wilayah di Nusa Tenggara Timur 33,1\%, diikuti Jawa barat $32,1 \%$ dan Bali $30 \%$. Prevalensi penyakit sendi berdasarkan provinsi, 


\section{Prosiding Seminar Nasional Kesehatan 2021 Lembaga Penelitian dan Pengabdian Masyarakat Universitas Muhammadiyah Pekajangan Pekalongan}

prevalensi untuk Sulawesi Utara berdasarkan diagnosis tenaga kesehatan sebesar $10,3 \%$ dan berdasarkan diagnosis tenaga kesehatan ditambah gejala klinik sebesar $19,1 \%$.

Penyakit arthrithis gout atau biasa disebut asam urat adalah penyakit sendi disebabkan karena tingginya asam urat dalam darah melebihi batas normal menyebabkan penumpukan dalam persendian dan organ tubuh lainnya. Penumpukan ini yang membuat sendi sakit, nyeri, dan meradang (Susanto, 2013). Asam urat merupakan penyakit yang diakibatkan oleh adanya gangguan metabolisme pada purin. Gangguan yang terjadi pada metabolisme purin menyebabkan penimbunan sodium orat di dalam dan diantara persendian. Penyakit asam urat ditandai dengan tingginya kadar asam urat dalam darah ( Haryono \& Setianingsih, 2013).

Sesorang yang mengalami asam urat dapat disebabkan oleh beberapa faktor, salah satunya yaitu pola makan yang tidak terkontrol dan sering mengkonsumsi makanan yang mengandung purin tinggi, yang mengakibatkan kadar asam urat dalam darah meningkat (Anies, 2018). Lokasi persendian yang terkena sering terjadi pada jari tangan dan jari kaki, bila kristal urat tertimbun pada jaringan kulit yang berisi kristal urat, juga dapat menyebabkan batu asam urat atau batu ginjal kemudian penyakit Gout lebih sering terjadi pada pria dibandingkan wanita dengan perbandingan hampir $90-95 \%$ menyerang pria, dan sisanya menyerang wanita terutama wanita yang menopause atau usia diatas 50 tahun (Handriani, 2011).

Gejala penyakit asam urat yaitu terasa ngilu, linu nyeri, dan kesemutan di sendi. Serangan awal mula biasanya terjadi di sendi pangkal ibu jari kaki sekitar $80 \%$ kasus. Sendi membengkak dan kulit di atasnya tampak kemerahan atau keunguan, kencang, licin serta hangat jika disentuh terasa sakit sekali. Gejala berangsur hilang tidak timbul gejala sampai serangan berikutnya, rasa nyeri bisa datang kembali jika makanan yang di konsumsi mengandung purin tinggi (Susanto, 2013). Jurnal International Research Journal Of Pharmachy (2013) menyebutkan bahwa salah satu penatalaksanaan asam urat atau nyeri sendi yaitu dengan kompres hangat dengan durasi 20 menit selang 2 minggu rutin. Tindakan farmakologis yang dapat diberikan pada penderita asam urat yang mengalami nyeri ada beberapa diantaranya anti nyeri dan anti peradangan. Pada keperawatan komplementer ada terapi herbal tidak menggunakan bahan farmakologi yang digunakan yaitu jahe mempunyai banyak khasiat yaitu dapat menurunkan rasa nyeri sendi atau asam urat. Banyaknya penelitian tentang manfaat dan khasiat jahe yang terbukti ampuh untuk meredakan/menurunkan skala nyeri asam urat/nyeri sendi, maka jahe digunakan sebagai kompres pada penderita asam urat atau nyeri sendi (Tim Lentera, 2015,p.2).

\section{Metode}

\section{Rancangan Penelitian}

Rancangan Penelitian menggunakan rancangan studi kasus. Rancangan studi kasus menurut Nursalam (2017) adalah rancangan yang mencakup pengkajian untuk memberikan gambaran mengenai latar belakang dan karakter dari suatu kasus. Penelitian ini dilakukan dengan metode secara sistematis mulai dari melakukan observasi, pengumpulan data, menganalisis informasi dan pelaporan hasil. Rancangan 


\section{Prosiding Seminar Nasional Kesehatan Lembaga Penelitian dan Pengabdian Masyarakat Universitas Muhammadiyah Pekajangan Pekalongan

Penelitian ini tentang penerapan Kompres Jahe Untuk Mengurangi Nyeri Pada Lansia Penderita Asam Urat

\section{Subjek Studi Kasus}

Rancangan penelitian ini menggunakan metode deskriptif. Metode deskriptif dengan desain studi kasus adalah salah satu jenis metode yang digunakan untuk menganalisis data dengan cara mendeskripsikan atau menggambarkan data yang telah terkumpul sebagaimana adanya tanpa bermaksud membuat kesimpulan yang berlaku untuk umum atau generalisasi (Donsu, 2016). Studi kasus dalam Penelitian ini adalah tentang penerapan kompres jahe untuk mengurangi nyeri pada lansia penderita asam urat.

\section{Fokus studi}

Fokus penulisan pada Penelitian ini adalah penerapan kompres jahe untuk mengurangi nyeri asam urat pada lansia yang mengalami penyakit asam urat

\section{Tempat dan Waktu Pengambilan Studi Kasus}

Penulis melakukan penerapan yang akan bertempat di Desa Sidorejo Kecamatan Comal Kabupaten Pemalang.

\section{Hasil dan Pembahasan Hasil}

\section{Kasus 1 (Ny.W)}

Hasil pengkajian pada Ny.W yang dilakukan pengkajian pada tanggal 25 Meil 2021 pada jam 10.00 WIB di Desa Sidorejo Kecamatan Comal Kabupaten Pemalang, Hasil pengkajian didapatkan pasien Ny.W usia 65 tahun jenis kelamin perempuan, alamat Desa Sidorejo Kecamatan Comal Kabupaten Pemalang, bersuku jawa, bangsa Indonesia, Pendidikan SD, Komunikasi dengan bahasa jawa.

Tipe keluarga Ny.W adalah keluarga tunggal yang dalam satu keluarga terdiri ibu, anak, pasien beragama islam, pendapatan Ny.W mengandalkan kerja ART dan anaknya setiap 1 bulan sekali mendapat kiriman Rp. 500.000.-. Saat ini Ny.W dan anaknya yang sudah bekerja dapat menghasilkan pendapatan, tahap perkembangan keluarga Ny.W terpenuhi.

Keluhan utama Ny.W mengatakan sudah 4 bulan pasien mengeluh nyeri dan berjalan sulit, P: pasien mengatakan nyeri saat aktivitas, Q: pasien mengatakan nyeri seperti ditusuk-tusuk, R: pasien mengatakan nyeri pada bagian lutut dan tengkuk belakang, S: skala nyeri 5, T: pasien mengatakan nyeri hilang timbul. Riwayat kesehatan keluarga dalam keluarga Ny.W tidak ada yang mengalami penyakit keturunan dan penyakit menular. Hasil dari pemeriksaan fisik didapat kesadaran umum compos mentis, kadar asam urat $8.5 \mathrm{mg} / \mathrm{dl}$ TD 120/80 mmHg, Suhu 36 C, Nadi 80 kali/menit, RR 20 kali/menit, BB $65 \mathrm{~kg}$, TB $158 \mathrm{~cm}$, dari fokus pemeriksaan didapatkan hasil Paru-paru Inspeksi: bentuk dada simetris, tidak ada lesi, Palpasi: tidak ada benjolan, Perkusi: bunyi paru normal, Auskultasi: suara normal vesikuler, hasil dari pemeriksaan jantung Inspeksi : tidak ada pembesaran jantung, Palpasi: tidak ada nyeri tekan, Perkusi: batas jantung normal, Auskultasi : suara jantung normal. 


\section{Prosiding Seminar Nasional Kesehatan 2021 Lembaga Penelitian dan Pengabdian Masyarakat Universitas Muhammadiyah Pekajangan Pekalongan}

\section{Kasus II (Ny. N)}

Hasil pengkajian pada Ny.N yang dilakukan pengkajian pada tanggal 26 Mei 2021 pada jam 13.00 WIB di Desa Sidorejo Kecamatan Comal Kabupaten Pemalang, Hasil pengkajian didapatkan pasien Ny.C usia 61 tahun jenis kelamin perempuan, alamat Desa Sidorejo Kecamatan Comal Kabupaten Pemalang, bersuku jawa, bangsa Indonesia, Pendidikan SMA, Komunikasi dengan bahasa jawa.

Tipe keluarga Ny. $\mathrm{N}$ adalah keluarga inti yang dalam satu keluarga terdiri ayah, ibu, anak, pasien beragama islam, pendapatan Ny.N masih bekerja sebagai perangkat desa dan suami masih berkerja sebagai buruh. Saat ini Ny.N tahap perkembangan keluarga Ny. $\mathrm{N}$ terpenuhi.

Keluhan utama Ny.N mengatakan sudah 3 bulan pasien nyeri di bagian kaki saat aktivitas, P: pasien mengatakan nyeri aktivitas berjalan, Q: pasien mengatakan nyeri seperti ditusuk-tusuk, R: pasien mengatakan nyeri pada bagian tumit, S: skala nyeri 5, $\mathrm{T}$ : pasien mengatakan nyeri hilang timbul. Riwayat kesehatan keluarga dalam keluarga Ny.N tidak ada yang mengalami penyakit keturunan dan penyakit menular. Hasil pemeriksaan fisik didapatkan kesadaran umum compos mentis kadar asam urat : 7,6 $\mathrm{mg} / \mathrm{dl}$ TD : 130/90 mmHg, Suhu 36, Nadi 80 kali/menit, BB : $65 \mathrm{~kg}$, TB : $159 \mathrm{~cm}$, dari fokus pemeriksaan didapatkan hasil Paru-paru Inspeksi: bentuk dada simetris, tidak ada lesi, Palpasi: tidak ada benjolan, Perkusi: bunyi paru normal, Auskultasi: suara normal vesikuler, hasil dari pemeriksaan jantung Inspeksi : tidak ada pembesaran jantung, Palpasi: tidak ada nyeri tekan, Perkusi: batas jantung normal, Auskultasi : suara jantung normal.

\section{Pembahasan}

Dari hasil penelitian dapat disimpulkan pada studi kasus ini bahwa kompres jahe dapat menurunkan skala nyeri pada lansia. Pada kasus satu kunjungan pertama skala nyeri 5 kadar asam urat 8,5 mg/dl, dan kunjungan ketiga skala nyeri menjadi 2 kadar asam urat $7,5 \mathrm{mg} / \mathrm{dl}$. Pada kasus kedua kunjungan pertama skala nyeri 4, kadar asam urat 7,6 mg/dl dan kunjungan ketiga skala nyeri menjadi 2, 5 kadar asam urat 7,0 $\mathrm{mg} / \mathrm{dl}$. Hasil studi kasus menunjukan bahwa tindakan kompres jahe dapat menurunkan skala nyeri, hasil studi kasus sesuai dengan penelitian Setelah dilakukan terapi nonfarmakologi (kompres jahe) selama 1 sampai 2 minggu rutin berpengaruh pada penurunan kadar asam urat pada lansia (Tim Lentera, 2015). Aida (2013), bahwa pemberian kompres dingin jahe juga mampu mengurangi nyeri sendi meskipun lebih baik jika menggunakan kompres hangat. Demikian juga dengan hasil penelitian Rusnoto (2014), juga memperoleh hasil bahwa pemberian kompres jahe efektif untuk mengurangi nyeri pada penderita asam urat yang mana setelah dilakukan uji wilcoxon juga memperoleh nilai $p=<0,05$.

\begin{tabular}{|l|l|l|l|}
\hline \multicolumn{1}{|c|}{$\begin{array}{c}\text { Hari } \\
\text { Melakukan }\end{array}$} & $\mathrm{n}$ & Median (Minimum Maksimum) & $\mathrm{P}$ \\
\hline Sebelum melakukan & & 5 & 0,05 \\
\hline Hari Pertama & 10 & 5 & 0,05 \\
\hline Hari Kedua & 10 & 3 & 0,04 \\
\hline Hari Ketiga & 10 & 2 & 0,02 \\
\hline
\end{tabular}




\section{Prosiding Seminar Nasional Kesehatan Lembaga Penelitian dan Pengabdian Masyarakat Universitas Muhammadiyah Pekajangan Pekalongan

\section{Kesimpulan}

Hasil studi kasus dapat menurunkan skala nyeri diharapakan kompres jahe ini dapat menjadi terapi nonfarmakologis pada lansia yang mengalami asam urat, dapat digunakan untuk menambah literature mengenai asuhan keperawatan pada lansia yang mengalami asam urat, dapat digunakan untuk menambah ilmu pengetahuan, pengalaman, dan kemampuan penulis dalam melakukan studi kasus pada pasien lansia penderita asam urat, dapat digunakan sebagai bahan pertimbangan untuk tindakan keperawatan untuk menurunkan skala nyeri.

\section{Referensi}

[1] Donsu, Jenita D.T. (2016). Metodologi Penelitian Keperawatan. Yogyakarta : Pustaka Baru Press. Hermayudi \& Ariani, A.P

[2] Handriani. (2011). Buku Ajar keperawatan Medikal Bedah (Edisi 8). (Vol 3). EGC: Jakarta.

[2] Haryono, R. \& Setianingsih, S. ( 2013). Musuh-musuh Anda setelah Usia 40 Tahun. Yogyakarta : Gosyen Publishing.

[3] Jaliana, Suhadi \& Sety L.O.M. (2018). Faktor-faktor Yang Berhubungan Dengan Kejadian Asam Urat Pada Usia 20 - 44 Tahun Di RSUD Bahteramas Provinsi Sulawesi Tenggara Tahun 2017. Jurnal IImiah Mahasiswa Kesehatan Masyarakat, 3(2), 1-4. Diambil dari : ojs.uho.ac.id.

[4] Kemenkes. (2013). Riset Kesehatan Dasar. Jakarta : Badan Penelitian dan Pengembangan Kesehatan

[5] Nursalam. (2017). Metodologi Penelitian IImu Keperawatan Pendekatan Praktis. Jakarta : Salemba Medika

[6] Susanto, Teguh. (2013). Asam Urat Deteksi, Pencegahan, Pengobatan. Yogyakarta : Buku Pintar.

[7] Tim Lentera. (2015). Khasiat dan Manfaat Jahe. AP. Agro Media Pustaka : Jakarta 